Dunamis: Jurnal Teologi dan Pendidikan Kristiani

Volume 6, Nomor 1 (Oktober 2021)

ISSN 2541-3937 (print), 2541-3945 (online)

https://www.sttintheos.ac.id/e-journal/index.php/dunamis

DOI: 10.30648/dun.v6i1.439

Submitted: 10 Oktober 2020

Accepted: 11 Februari 2021

Published: 31 Oktober 2021

\title{
Memaknai Ulang Ecclesia Domestica di Masa Pandemi Covid-19
}

\author{
Antonius Galih Arga W. Aryanto ${ }^{1 *}$; Martinus Joko Lelono ${ }^{2}$ \\ Fakultas Teologi Universitas Sanata Dharma ${ }^{1}$; Inter-Religious Studies, Sekolah Pasca Sarjana \\ Universitas Gadjah Mada ${ }^{2}$ \\ galiharga@usd.ac.id*
}

\begin{abstract}
The pandemic covid-19 has compeled Catholic families to pray at home instead of going to the Church every Sunday, and it changed the expression of their faith. This new condition helped families to realize their role as formators of spiritual life for the family members. The purpose of this research was to look out how the social distancing effects the role of the family as the formator for faith formation of their children during pandemic covid-19. The research conducted by qualitative and quantitative approach toward fivety Catholic families. Through this research it was shown that during covid-19 pandemic family had a big chance of doing the role as the Church Family (ecclesia domestica) that emphasizing the future mission of the Church is depending on the family life. The Church Family is understood as the smallest cell of the Church as the sacrament, the visible sign of God, and becomes a place for encountering the faithful to Jesus Christ in the world.
\end{abstract}

Keywords: Family Church; Catholic family; covid-19 pandemic; sacrament; Sunday School

\begin{abstract}
Abstrak
Pandemi covid-19 telah memaksa keluarga-keluarga Kristiani untuk beribadah di rumah dan mengubah cara menggereja mereka. Situasi itu menjadikan keluarga menyadari perannya sebagai pembina utama hidup rohani anggota keluarga. Penelitian ini bertujuan untuk melihat bagaimana pengaruh pembatasan sosial terhadap peran keluarga dalam pendidikan iman anak di masa pandemi covid-19. Penelitian ini menggunakan pendekatan kuantitatif dan kualitatif terhadap 50 keluarga Katolik. Melalui penelitian ini diperoleh gambaran bahwa dalam masa pandemic covid-19 ini keluarga berkesempatan menjalankan peran sebagai Gereja keluarga (ecclesia domestica) yang menekankan masa depan pewartaan Gereja adalah melalui hidup keluarga. Gereja keluarga dipahami sebagai sel terkecil yang menjadi bagian dari Gereja sebagai sakramen, tanda yang kelihatan dari Allah, dan menjadi medan pertemuan orang beriman dengan Yesus Kristus di dunia.
\end{abstract}

Kata Kunci: ecclesia domestica; Gereja keluarga; keluarga Katolik; pandemi covid-19; sakramen; Sekolah Minggu 


\section{PENDAHULUAN}

Sebagai usaha untuk memutus rantai penyebaran Corona Virus Desease 19 (covid-19), pemerintah meminta masyarakat untuk mengurangi pertemuan dalam skala besar. Masyarakat Indonesia dipaksa untuk membuat berbagai bentuk adaptasi baru. Pemuka berbagai agama mendorong umatnya mengikuti dan mengadakan peribadatan di rumah masing-masing. Penelitian ini memfokuskan diri kepada pengaruh pembatasan relasi sosial terhadap pendidikan iman anak di dalam keluarga Katolik. Di dalamnya dibahas tentang bagaimana umat Katolik beradaptasi dari peribadatan yang berpusat di gereja menjadi peribadatan yang berpusat dalam keluarga. Di kalangan umat Katolik, sempat terjadi beberapa debat tentang apakah memungkinkan liturgi gereja diadakan terpisah dari kehadiran seorang tertahbis. Ada keraguan bahwa ibadat Katolik bisa dilakukan berjarak dari kehadiran bersama di dalam satu gereja.

Sebagai tanggapan atas keputusan pemerintah Indonesia demi penanganan pandemi Covid-19, para uskup Indonesia memutuskan untuk meniadakan seluruh perayaan Ekaristi dan berbagai kegiatan gereja yang melibatkan banyak orang. ${ }^{1}$ Berbagai paroki sudah tidak mengadakan peraya-

\footnotetext{
1 “Antisipasi Corona, Sejumlah Gereja Katolik Di Keuskupan Jakarta Dan Semarang Gelar Ibadah Online - Minews ID,” accessed April 28, 2020,
}

an Ekaristi bersama umat baik perayaan Ekaristi harian maupun mingguan sejak Minggu 22 Maret 2020. Situasi baru akibat pandemi covid-19 menuntut umat berdoa di dalam keluarga. Altar gereja berpindah dari gedung gereja ke dalam meja rumah keluarga.

Tidak adanya Perayaan Ekaristi bersama umat di Gereja membawa beberapa konsekuensi terutama berhubungan dengan peran keluarga sebagai pusat hidup rohani dengan orang tua sebagai pemimpin spiritual keluarga. Memang benar bahwa para pastor masih menyediakan Perayaan Ekaristi secara online, tetapi hal itu hanya memberi masukan rohani yang terbatas kepada hidup spiritual bagi anggota keluarga. Berbagai pendalaman rohani yang biasanya tersedia untuk anggota keluarga, sekarang tidak ada lagi. Sekolah Minggu atau Bina Iman anak tidak mungkin dilakukan lagi. Pendalaman iman untuk orang tua tidak lagi ada di lingkungan. Berbagai bentuk pengolahan rohani di berbagai jenjang usia menjadi sangat terbatas atau bahkan tidak berjalan lagi. Hal ini menimbulkan kekagetan di antara keluarga-keluarga Katolik.

Selama bertahun-tahun keluargakeluarga Katolik menyerahkan pendampingan iman anak kepada gereja dan juga se-

https://www.minews.id/news/antisipasi-coronasejumlah-gereja-katolik-di-keuskupan-jakarta-dansemarang-gelar-ibadah-online. 
kolah baik dalam pendampingan iman anak maupun pelajaran agama di sekolah. Beberapa dari mereka bahkan tidak memiliki kebiasaan doa keluarga. Usaha pendalaman iman keluarga biasanya dilakukan dengan sekedar mengikuti Perayaan Ekaristi atau ibadah di lingkungan. Bagi institusi gereja, situasi ini menjadi kesempatan untuk berefleksi tentang pentingnya peran Gereja Keluarga. Hal itu berkaitan dengan pendidikan rohani anak-anak yang memang tidak bisa diserahkan hanya kepada gereja dan sekolah. $^{2}$

Dampak Covid-19 membuat pemimpin agama membutuhkan sudut pandang baru untuk melihat dinamika hidup gereja dengan fokus keluarga sebagai pusat hidup beriman. Studi ini berusaha menelaah sejauh mana keluarga-keluarga Kristiani mengusahakan diri menjadi pusat hidup spiritual iman keluarga di masa pandemi. Peran bapak dan ibu keluarga bertambah dengan menjadi guru iman bagi anak-anak mereka. Pertanyaannya adalah bagaimana orang tua mendampingi anak-anak dalam perkembangan iman saat peran gereja berkurang dalam soal pengajaran iman?

\section{METODE PENELITIAN}

Paper ini hendak mengadakan penelitian kualitatif untuk memberi tekanan pa- da pendidikan anak di dalam keluarga Kristiani. Sementara pada masa normal biasa pendidikan iman ini banyak diserahkan kepada gereja dan sekolah, pandemi covid19 menantang keluarga untuk menjadi pusat kehidupan rohani bagi anak-anaknya. Guna melihat lebih dalam gambaran mengenai berbagai rasa syukur atas kesempatan memiliki waktu berdoa bersama, penelitian kualitatif ini diperdalam dengan angket yang disampaikan kepada lima puluh keluarga Katolik dengan rentang usia pernikahan antara 1 sampai 30 tahun yang sudah memiliki anak. Rentang usia ini dipilih dengan alasan bahwa mereka memiliki peran untuk mengadakan pendidikan iman kepada anak. Penelitian ini diperkaya oleh pendalaman dengan wawancara mendalam terhadap keluarga-keluarga guna menemukan narasi-narasi yang melengkapi penelitian kuantitaif. Pendalaman ini berfungsi untuk mengenali lebih dalam bagaimana dampak pandemi covid-19 ini terhadap kesadaran akan pentingnya mengupayakan Gereja Keluarga.

\section{HASIL DAN PEMBAHASAN}

\section{Ketika Altar Berpindah ke Ruang Domestik Keluarga}

Pada masa pandemi, Gereja Katolik Indonesia menyediakan pelayanan Ekaristi

\footnotetext{
2 Paulus VI, “Gravissimum Educationis," Retrieved May 19 (Jakarta: Dokpen KWI, 1965): Art 3.
} 
melalui layanan daring. Dalam beberapa kesempatan, terdapat komentar dari umat atas perayaan online tersebut. Data ini diambil dari layanan Ekaristi Online di channel YouTube Komisi Komunikasi Sosial Keuskupan Agung Semarang. Di antara mereka ada yang mengungkapkan kesedihan karena tidak bisa mengikuti Perayaan Ekaristi secara langsung. Muncul pula beberapa ungkapan syukur. Seorang umat mengatakan, "Situasi ini menjadikan kami bisa mengikuti Ekaristi bersama. Selama bertahun-tahun, kami jarang ikut Ekaristi sebagai keluarga karena berbagai alasan. Amat baiklah bahwa sekarang kita punya misa online bersama dan bisa berefleksi bersama berdasarkan bacaan Kitab Suci." Umat yang lain bernama Putri mengatakan, "Sejak kami mengikuti Perayaan Ekaristi secara online baik Ekaristi harian maupun mingguan, kami jadi punya waktu untuk berdoa bersama dalam keluarga. Saya rasa ini adalah cara Tuhan untuk menyatukan kami." Salah satu ibu keluarga bernama Ita merefleksikan bahwa situasi ini adalah rahmat di balik derita (blessing in disguise). Dia mengatakan, "Jarang-jarang kami memiliki waktu bersama tetapi sekarang kami punya banyak waktu bersama. Lebih dari itu, kami jadi lebih punya waktu untuk berdoa di da-

\footnotetext{
${ }^{3}$ Inspirasi Hidup\#4: Ini Dia, Harta Yang Melebihi Emas Permata, accessed April 28, 2020, https://www.youtube.com/watch?v=iulZwzDZ3bo $\& \mathrm{t}=7 \mathrm{~s}$; Homili Bapa Uskup Agung Mgr. Robertus
}

lam Keluarga.” Dalam ungkapan yang serupa, Wijayanti mengatakan bahwa saat ini ketika keluarga bisa mengatur waktu dengan lebih baik, ada kesempatan untuk doa keluarga yang membuat hubungan antar anggota keluarga menjadi lebih erat. ${ }^{3}$

\section{Data Kuesioner}

\begin{tabular}{|c|c|c|c|}
\hline $\begin{array}{l}\text { Sadar akan } \\
\text { tanggung } \\
\text { jawab } \\
\text { mendidik } \\
\text { berdasar } \\
\text { iman } \\
\text { Kristiani } \\
\end{array}$ & $\begin{array}{l}\text { Bentuk } \\
\text { Pendidikan } \\
\text { iman anak } \\
\text { dari keluarga }\end{array}$ & $\begin{array}{l}\text { Adakah } \\
\text { perbedaan } \\
\text { dalam } \\
\text { pendidikan } \\
\text { iman sesudah } \\
\text { pandemic } \\
\text { covid-19? }\end{array}$ & $\begin{array}{l}\text { Bentuk } \\
\text { pendidikan } \\
\text { iman anak } \\
\text { di masa } \\
\text { pandemi }\end{array}$ \\
\hline \multirow[t]{3}{*}{$\begin{array}{l}(50 \mathrm{kelg}- \\
100 \%)\end{array}$} & $\begin{array}{l}\text { Diserahkan } \\
\text { ke sekolah } \\
(18 \text { kelg - } \\
36 \%)\end{array}$ & $\begin{array}{l}\text { Ada bedanya } \\
(32 \mathrm{kelg}- \\
64 \%)\end{array}$ & $\begin{array}{l}\text { Ikut } \\
\text { Ekaristi } \\
\text { online } \\
(42 \text { kelg - } \\
84 \%)\end{array}$ \\
\hline & $\begin{array}{l}\text { Ikut Sekolah } \\
\text { Minggu } \\
(34 \text { kelg - } \\
68 \%)\end{array}$ & $\begin{array}{l}\text { Tidak ada } \\
\text { bedanya } \\
(18 \text { kelg - } \\
36 \%)\end{array}$ & $\begin{array}{l}\text { Berdoa } \\
\text { Bersama } \\
(41 \text { kelg - } \\
82 \%)\end{array}$ \\
\hline & $\begin{array}{l}\text { Ikut acara } \\
\text { iman (misa, } \\
\text { rosario, } \\
\text { pertemuan } \\
\text { lingkungan) } \\
(19 \text { kelg - } \\
38 \%) \\
\text { Berdoa } \\
\text { bersama } \\
\text { keluarga } \\
(41 \text { kelg - } \\
82 \%)\end{array}$ & & $\begin{array}{l}\text { Cerita } \\
\text { Kitab Suci } \\
(2 \mathrm{kelg}- \\
4 \%)\end{array}$ \\
\hline
\end{tabular}

Dari penelitian, ditemukan fakta bahwa keluarga-keluarga ini menyadari perannya untuk mengusahakan pendidikan iman bagi anak-anak mereka. Namun, secara umum mereka menyerahkan peran pendidikan ini kepada gereja dan sekolah. Dela-

Rubiyatmoko: "Sukacita Dalam Kerinduan Akan Allah.," accessed April 28, 2020, https://www. youtube.com/watch?v=UCMcREUEfRg $\& \mathrm{t}=3 \mathrm{~s}$. 
pan belas keluarga (36\%) menyerahkan pendidikan iman anak terutama pada sekolah dan tiga puluh empat keluarga (68\%) membawa anaknya untuk mengikuti Sekolah Minggu. Ungkapan iman keluarga terutama ditampakkan dalam doa bersama keluarga yang dilakukan oleh empat puluh satu keluarga (82\%). Dalam rangka mendukung hidup rohani anak-anak mereka, banyak orang tua menyerahkan pendidikan iman anaknya dalam acara Sekolah Minggu (68\%) atau pendampingan iman anak, pendampingan iman remaja dan juga pelajaran agama di sekolah (36\%). Adapula keluarga yang mengajak anak-anaknya mengikuti pertemuan jemaat lingkungan untuk berdoa bersama dan pendalaman iman $(38 \%)$.

Menanggapi pertanyaan, “Apakah keluarga Anda memiliki waktu berdoa di dalam keluarga?" Sebagian besar dari mereka menjawab bahwa mereka memiliki waktu doa tapi tidak rutin dilakukan. Di antara lima puluh keluarga ada 41 keluarga (82\%) yang memiliki kebiasaan doa keluarga. Mereka, yang memiliki kebiasaan doa keluarga, mengakui bahwa kebiasaan doa itu belum bisa dilakukan secara rutin. Dalam angket kepada lima puluh keluarga ditemukan beberapa alasan mengapa kebiasaan doa keluarga tidak rutin dilakukan: kesibukan masing-masing pribadi; jadwal yang berbeda-beda; tidak pernah bisa menentukan waktu bersama; selalu saja ada yang menunda; dan tidak ada antusiasme untuk melakukannya.

Dalam survei kepada lima puluh keluarga di Jawa Tengah dan Yogyakarta, secara umum keluarga-keluarga Katolik merefleksikan bahwa di masa pandemi mereka perlu memikirkan kegiatan rohani baru untuk memenuhi kebutuhan rohani keluarga. Hal ini mengingat bahwa mereka tidak lagi bisa mengandalkan gereja (di tingkat Paroki, wilayah maupun lingkungan), dan sekolah. Pilihan yang paling popular adalah mengikuti Perayaan Ekaristi streaming sebagai sarana untuk menggantikan keikutsertaan dalam Perayaan Ekaristi hari Minggu. Dalam menjawab pertanyaan, "Di masa pandemi akibat Covid-19 ini, keluarga-keluarga mempunyai waktu lebih lama di dalam kebersamaan, termasuk peran lebih di dalam hal rohani mengingat tidak ada kegiatan rohani bersama di Gereja. Bagaimana Anda menjalankan peran 'Mendidik anak-anak secara Katolik'? (Jawaban bisa lebih dari satu)," terdapat empat puluh dua keluarga (84\%) yang terlibat di dalam Perayaan Ekaristi Online mingguan di rumah masing-masing. Bagi sebagian keluarga yang lain, rupanya Perayaan Ekaristi secara online tidak dirasa cukup sebagai pengganti begitu banyak olah rohani yang biasanya dilakukan dalam berbagai kegiatan. Terdapat tiga puluh dua keluarga (64\%) yang menyatakan bahwa mereka memikirkan bahwa 
anak-anak mereka memerlukan pendampingan iman secara khusus mengingat situasi yang memisahkan mereka dari gereja dan sekolah yang biasanya menjadi tempat pendampingan iman anak.

Dalam menjawab pertanyaan yang sama mengenai pendampingan iman khusus di masa pandemi, sebagian besar umat menyadari pentingnya mengupayakan cara baru pendidikan iman di masa pandemi. Selain mengikuti Ekaristi secara online pada hari minggu, mereka mengupayakan doa keluarga. Namun tidak banyak yang mendidik anak dengan membacakan Kitab Suci sebagai sarana doa. Di antara keluarga-keluarga tersebut terdapat keluarga-keluarga yang mengupayakan pendampingan iman anak yang biasanya dilakukan di dalam Sekolah Minggu atau pendidikan agama di sekolah: menghafal doa Katolik, membaca dan menceritakan kisah Kitab Suci, mewarnai kartu Paskah dan juga menggambari telur Paskah. Ada beberapa yang membantu anaknya untuk memiliki kepedulian kepada mereka yang menderita akibat pandemi covid-19. Kecuali doa bagi selesainya pandemi ini, anak-anak juga diajak untuk berpartisipasi dalam karya amal kasih. Di dalam ide-ide untuk mengupayakan berbagai kegiatan rohani di dalam kelaurga ini, terdapat kesadaran bersama bahwa keluarga harus mengambil inisiatif untuk mendukung hidup rohani seluruh anggota keluarga terutama bagi anak-anak.

Peristiwa pandemi covid-19 rupanya menjadi pintu masuk bagi keluarga-keluarga untuk kembali mengingat pentingnya waktu berdoa dalam keluarga. Studi ini mengadakan pendalaman atas kuesioner yang dilakukan beberapa keluarga yang menjadikan kesempatan pandemi ini untuk mendekatkan keluarga melalui doa keluarga._Beberapa keluarga ini dipilih atas dasar usia perkawinan yang berbeda-beda. Namanama disamarkan untuk menjaga privasi dari pribadi yang bersangkutan. Ibu Siska mengatakan bahwa kesempatan pandemi ini bisa menjadikan keluarga mereka memiliki kesempatan untuk misa bersama dalam keluarga yang biasanya tidak mudah dijalani. Dia mengatakan, "Bapak biasa misa pagi di gereja. Saat masa pandemi beliau melakukan misa online, bahkan sekarang bisa diikuti oleh semua keluarga." Lain lagi dengan keluarga Ibu Ita yang mengatakan bahwa kesempatan untuk berada di rumah dalam waktu yang lama memberi kesempatan kepada keluarga ini untuk memiliki doa rutin. Dia mengatakan bahwa pada masa-masa normal ada banyak kegiatan di luar rumah juga pada malam hari, baik kegiatan di lingkungan umat Katolik maupun masyarakat secara umum. Dalam masa pandemi covid19, saat waktu lebih memungkinkan, mereka memiliki kesempatan untuk berdoa ber- 
sama. Anak-anak juga ikut. Keluarga Pak Ozi mengupayakan ada doa malam di dalam keluarga sembari menjadi kesempatan untuk memberikan petuah-petuah untuk anaknya. Sementara untuk keluarga ibu Ris kebiasaan doa ini menjadi hal yang harus diupayakan mengingat memang tidak pernah menjadi pemikiran sebelumnya.

Dalam keluarga-keluarga ini misa online dirasa menjadi kesempatan untuk mengumpulkan keluarga, sembari menambah dengan doa malam bersama di dalam keluarga. Beberapa tekanan dilakukan di dalam keluarga ini. Keluarga Ibu Siska menekankan doa-doa Gereja seperti rosario, novena dan koronka sebagai pendukung bagi keluarga. Keluarga yang lain memberi kesempatan untuk berdoa secara pribadi. Keluarga Ibu Ris menceritakan bagaimana mereka semakin tergugah untuk menjadi dekat dengan Tuhan dan sesama. Doa-doa mereka biasanya sekitar masalah corona dan terselesainya masalah dan juga permohonan kebaikan untuk semua orang terutama para tenaga medis, mereka yang sakit dan juga kesehatan untuk keluarga. Berbeda lagi dengan keluarga Bapak Ozi yang menjadikan saat-saat doa sebagai kesempatan untuk bersyukur. Hal ini senada dengan ungkapan ibu Ita yang menyebut tentang syukur bahwa masih diberi rezeki untuk kehidupan. Kesempatan doa menjadi kesempatan untuk mengajari rasa syukur di dalam keluarga. Hal ini mengamini ungkapan dari ibu Ris yang mengatakan bahwa, "Jadi biasanya tuh rasanya kita yang mencari Tuhan, sekarang rasanya Tuhan hadir ke rumah kita masing-masing. Kadang pada kondisi normal tuh sering males-malesan, sekarang ya rasanya kangen ke gereja. Tapi berkumpul bersama keluarga seperti ini membuat doa bersama dan misa bersama menjadi terasa berharga sekali." Ada pemaknaan baru yang menjadikan relasi dengan Tuhan semakin dikuatkan. Terlebih lagi, upaya untuk mendekatkan diri dengan Tuhan itu diteguhkan oleh kedekatan dengan keluarga. Ini menjadi bagian dari kesadaran akan keluarga sebagai Gereja, persekutuan umat beriman.

Di tengah situasi yang demikian, hirarki gereja memberi beberapa bantuan yang sifatnya menjadi panduan. Kehadiran misa online sebagai sarana untuk menyapa umat dirasa sangat membantu. Umat memang merasa ada yang hilang dalam misa online terutama dengan ketiadaan penerimaan Tubuh Kristus. Namun, ada juga hal yang didapatkan yaitu kesempatan untuk memiliki waktu Ekaristi bersama dengan keluarga. Selain itu, gereja menyediakan "Doa Mohon Perlindungan dari Wabah Virus Corona" yang membantu permohonan umat di dalam situasi pandemi ini. Memang dorongan secara khusus untuk menjadikan kesempatan ini untuk menyadari pe- 
ran Gereja Keluarga tidak terlalu bergaung, tetapi kebutuhan akan pendampingan rohani yang dihadapkan dengan keterbatasan yang ada memberi kesempatan untuk mencari Tuhan di dalam kebersamaan keluarga. Ibu Ris mengatakan, "Selama pandemi ini keluarga sebagai gereja terkecil menjadikan kami masing-masing semakin dekat dalam kebersamaan kami. Kami merasa Tuhan hadir di tengah-tengah kami, dan menguatkan kami. Lebih-lebih, kami juga semakin saling mendukung dan rasanya lebih ayem." Senada dengan ini, Ibu Ita mengatakan, "Dalam kebersamaan ini, hati lebih adem dan tenang!' Dengan kesadaran yang serupa, Ibu Siska mengatakan bahwa di dalam situasi ini, doa-doa membantu keluarganya menjadi lebih mudah bersyukur, sabar dan menerima anugerah Allah dalam bentuk apapun. Dengan situasi yang khas, Bapak Ozi mengungkapkan rasa syukurnya, "Setelah doa malam, anak saya langsung tertidur pulas. Secara spontan bersyukur ketika melihat wajah anak saya yang tertidur dengan nyenyaknya. Damai sekali. Bersyukur karena dipercaya mendidiknya, bersyukur karena diberi kekuatan untuk mendidiknya. Intinya, saya bersyukur atas semua berkat yang diberikan kepada kami bertiga."

Berbagai uraian di atas memberi kita gambaran bahwa pandemi covid-19 me-

\footnotetext{
4 Karol Wojtyla, Love and Responsibility (New
} York: Farrar, Straus, Giroux, 1981), 242. maksa banyak keluarga untuk menemukan muara rohani di dalam keluarga. Peran orang tua untuk memberi teladan dalam keluarga menjadi penting dan situasi pandemi covid-19 memungkinkan hal itu. Ungkapan “Keluarga sebagai Gereja terkecil” yang selama ini terdengar klise, sekarang menjadi sebuah kenyataan. Pandemi covid-19 memberi kesempatan untuk semakin menyadari peran keluarga sebagai tempat pertama dan utama untuk pertumbuhan iman keluarga, terutama anak-anak.

\section{Gereja Keluarga Tempat Awal Pendidikan Iman}

Perpindahan tempat ibadah dari gereja ke dalam rumah membawa kesadaran baru akan makna dari ecclesia domestica (Gereja Keluarga). Istilah Gereja Keluarga kembali dipopulerkan oleh Paus Yohanes Paulus II dalam surat apostoliknya tentang keluarga Kristiani (Familiaris Consortio). Paus Yohanes Paulus II mendefinisikan keluarga sebagai tempat pendidikan dasar anak-anak di mana personalitas seorang manusia dibentuk. ${ }^{4}$ Dia juga menekankan bahwa keluarga menjadi bagian terkecil dari komunitas yang menentukan existensi komunitas yang lebih besar, masyarakat, negara, dan gereja semua tergantung dari hidup keluarga. ${ }^{5}$

\footnotetext{
${ }^{5}$ Ibid., 217.
} 
Sebenarnya istilah ecclesia domestica sudah ada sejak masa Bapa Gereja seperti Agustinus dan Yohanes Krisostomus. Ide mereka dikembangkan saat diskusi-diskusi tentang masalah keluarga dalam persiapan Konsili Vatikan II tahun 1963. Paham ecclesia domestica mulai dari pandangan Pietro Fiordelli (1916-2004), seorang uskup dari Prato yang aktif dalam gerakan Keluarga Katolik. Dalam diskusi Konsili Vatikan II tentang struktur teologi dari keluarga, Fiordelli berkata, "Gereja paroki dibagi dalam banyak sel kecil yaitu keluarga. Keluarga adalah kehidupan terkecil dari Gereja Allah."6 Ada tiga dasar utama argumen Gereja keluarga. Pertama, keluarga-keluarga Kristiani tidak hanya anggota gereja tetapi juga organ-organ hidup dan komunitas dari tubuh Kristus. Kedua, Efesus 5:32 berbicara tentang hubungan Kristus dan jemaat. Keluarga Kristiani menjadi Gereja kecil karena di dalamnya ada komunikasi iman tentang misteri kesatuan Kristus dan Gereja. Ketiga, orang tua disucikan Gereja dalam tugas mereka sebagai pendidik anak-anak. ${ }^{7}$

Ide dasar Fiordelli menjadi fondasi bagi teologi keluarga sebagai Gereja terkecil, sel Gereja yang hidup. Bapak dan ibu keluarga menjalankan tugasnya sebagai

\footnotetext{
${ }^{6}$ Joseph C Atkinson, "Family as Domestic Church: Developmental Trajectory, Legitimacy, and Problems of Appropriation," Theological Studies 66, no. 3 (2005): 595-96.

${ }^{7}$ Fiordelli mengambil istilah "Gereja Keluarga" dari santo Agustinus dan Yohanes Krisostomus yang mengembangkan ide Gereja lokal. Agustinus
}

imam keluarga karena baptisan yang mereka terima. Mereka memimpin doa dan menjaga iman keluarga agar tumbuh dan berakar kuat serta mendalam. Gagasan itu masuk dalam dokumen Lumen Gentium (LG) art 11 yang menyebut, "Dalam Gereja keluarga (ecclesia domestica) itu hendaknya orangtua dengan perkataan maupun teladan menjadi pewarta iman pertama bagi anakanak mereka; orang tua wajib memelihara panggilan mereka masing-masing, secara istimewa penggilan rohani."

Dalam kesatuan dengan Gereja, keluarga Kristiani terbentuk pertama-tama karena baptisan yang diterima masing-masing anggota. Baptisan tidak hanya mengubah hidup orang, tapi secara ontologis menjadikan hidup orang dikuasai oleh Kristus. Relasi suami-istri ada dalam tata kekudusan karena kesatuan mereka dalam perkawinan. Seorang suami harus memberikan nyawanya untuk istrinya karena dia adalah kepala rumah tangga sebagaimana Kristus adalah kepala Gereja. Suami dipanggil untuk mengasihi istrinya sebagaimana ia mengasihi dirinya sendiri. Istripun harus mengasihi dan menghormati suaminya sebagaimana Gereja menghormati Kristus.

berkata dalam De Bono Viduitatis, "Cum tota domestica vestra ecclesia."

8 POPE PAUL VI, "Lumen Gentium," Encyclical Http://Www.Vatican.va/Archive/Hist_councils/Ii_v atican_council/Documents/Vatii_const_19641121_l umen-Gentium_en. Html, 1964, Art 11. 
Ide ecclesia domestica dari bapa Gereja seperti Agustinus dan Yohanes Krisostomus sebenarnya bersumber dari teologi Paulus tentang perkawinan dalam Efesus 5:21-33. Paulus memulai pembentukan jemaatnya dengan mengumpulkan mereka dalam komunitas-komunitas kecil dalam Gereja rumah tangga (Ekklēsia). ${ }^{9}$ Sebenarnya Gereja rumah tangga Paulus lebih menunjuk pada perkumpulan orang seiman yang percaya pada Kristus. Mereka berkumpul dalam sebuah rumah yang biasanya dimiliki oleh orang kaya yang sudah menjadi Kristen. Setidaknya ada 5-7 Gereja rumah tangga dalam komunitas Korintus dalam masa pelayanan Paulus di sana. ${ }^{10}$

Gereja keluarga memiliki andil besar dalam pewartaan Injil. Komitmen keluarga untuk hidup sederhana dan memperhatikan orang miskin memberi kesaksian ampuh pada orang lain dibanding kesaksian dari imam dan biarawan/wati. Masyarakat umum lebih mudah memahami dan melihat bagaimana kesaksian harian keluarga Katolik. Mereka mengapresiasi keluarga yang membantu orang lain dan melayani sesama dengan konsisten dan dalam jangka waktu yang relatif lama. ${ }^{11}$

\footnotetext{
9 Diskusi arti "Gereja Rumah Tangga" dibahas mendalam oleh Richard Last. Lih Richard Last, "The Neighborhood (Vicus) of the Corinthian Ekklēsia: Beyond Family-Based Descriptions of the First Urban Christ-Believers," Journal for the Study of the New Testament 38, no. 4 (2016): 399-425.

${ }^{10}$ Annette Weissenrieder, Thomas R Blanton, and Raymond Pickett, “Architecture: Where Did Pauline
}

Ide Gereja Keluarga memberi pemahaman baru pada pengertian peran Gereja dalam masyarakat. Keluarga Kristiani menjadi garda depan bagi karya misi Gereja, mereka tidak hanya menjadi menerima pasif dari karya karitatif Gereja semata. Setiap keluarga Kristiani dalam hidup harian mereka sungguh-sungguh mengekpresikan perhatian Gereja pada dunia. Namun demikian, Gereja keluarga tidak berdiri sendirian. Ia berada dalam kesatuan dengan Gereja lokal yang lebih besar. Yesus Kristus memanggil keluarga Kristiani dalam kesatuan dengan semua orang beriman dalam sakramen. Kesatuan itu ditampakkan dalam kesadaran akan misi yang diemban karena baptisan tiap anggota Gereja.

Ajaran Gereja Evangeli Nuntiandi (EN) memberi dasar lebih kuat bagi teologi Gereja keluarga sebagaimana diungkapkan oleh Paus Paulus VI. Pertama, setiap keluarga Kristiani memiliki berbagai aspek dari keseluruhan Gereja. Tidak hanya berfokus pada Pendidikan iman anak. Kedua, setiap keluarga perlu sadar akan panggilannya untuk bermisi bahwa semua anggota keluarga yang dibaptis perlu menyebarkan warta Injil Kristus. Ketiga, sebuah keluarga Kristiani

Communities Meet?" in Paul and Economics. A Handbook, (Minneapolis: Fortress Press, 2017), 125-53.

11 Florence Caffrey Bourg, "Domestic Church: A New Frontier in Ecclesiology," Horizons 29, no. 1 (2002): 42-63. 
menjadi pewarta Injil bagi keluarga lain dan lingkungan sekitar tempat mereka hidup. Keempat, dalam keluarga beda agama yang keduanya dibaptis dalam Kristus, panggilan mewartakan Injil tetap ada karena konsekuensi baptisan mereka. ${ }^{12}$

Paham Gereja Keluarga yang Eklesiologis dan Kristosentris memberi perspektif bagaimana keluarga memahami dan memandang dunia dan hidup. Baptisan, perkawinan dan perutusan pewartaan menjadi tanda publik yang membawa konsekuensi perutusan. Setiap keluarga dalam corak, kekhasan serta kedewasaannya mewujudkan hidup keluarga mereka sebagai tempat kehadiran Kristus yang nyata. Ecclesia domestica menjadi tempat nyata manusia untuk berelasi dengan Allah. Keluarga menjadi tanda rahmat Allah yang tampak dan terus berlangsung. Dengan demikian Gereja keluarga dipahami sebagai komunitas kecil yang menjadi bagian dari Gereja sebagai sakramen, tanda yang kelihatan dari Allah, dan menjadi medan pertemuan orang beriman dengan Yesus Kristus. ${ }^{13}$

Paus Yohanes Paulus II juga mengembangkan ide teologi keluarga dalam anjuran apostolik Familiaris Consortio (FC), "Keluarga akan menampakkan diri

12 Weissenrieder, Blanton, and Pickett, "Architecture: Where Did Pauline Communities Meet?" 56.

${ }^{13}$ Michael Skelley, The Liturgy of the World: Karl Rahner's Theology of Worship (Collegeville, MI: Liturgical Press, 1991). pada semua orang akan kehadiran sang penyelamat di dunia, dan keaslian dari ciri khas Gereja" (FC 50). Identitas keluarga memiliki dua kutub yaitu Kristus dan Gereja. Dalam kesatuan dengan Kristus, jati diri keluarga Kristiani bersumber dari tiga jabatan Kristus sebagai imam, nabi dan raja. Keluarga menjadi tempat pewartaan iman dan sebuah komunitas kecil yang percaya pada Yesus Kristus (jabatan kenabian). Keluarga menjadi tempat orang untuk berdialog dengan Allah secara mendalam (jabatan imam), dan keluarga menjadi tempat orang melayani sesama (jabatan raja). ${ }^{14}$

Dalam ajaran Gereja diatas, para orang tua memiliki peran sentral di dalam pendidikan anak. Khusus tentang pendidikan iman, keluarga memiliki kewajiban untuk menciptakan situasi yang memungkinkan anak-anak belajar untuk mencintai Tuhan dan sesama. Dari sini menjadi jelas bahwa pribadi, institusi Gereja dan lembaga pendidikan berperan sebagai pendukung bagi pendidikan keluarga. Memang di dalam masa modern ini, ada banyak peran pendidikan anak diserahkan kepada sekolah. Namun, orang tua untuk harus menciptakan iklim di mana keluarga menjadi tempat untuk tumbuh kembangnya cinta kasih

14 Atkinson, "Family as Domestic Church: Developmental Trajectory, Legitimacy, and Problems of Appropriation," 599. 
dan hormat kepada Allah dan sesama. Demikianlah kita menemukan makna pendidikan Kristiani dalam diri mereka yang sedang menjalani proses pendidikan. Pendidikan Kristiani tidak boleh disederhanakan semata pendidikan di sekolah maupun di gereja, tetapi lebih-lebih dalam pendidikan dalam keluarga. ${ }^{15}$ Harls Evan Rianto Siahaan menyebutkan, "Suasana belajar secara prinsip adalah suasana berbicara dan mendengar, termasuk pendidikan Kristiani. Dalam kaitannya dengan iman Kristen, maka pendidikan Kristiani menitikberatkan mendengar sebagai roh dalam pencapaian tujuan." ${ }^{16}$ Dengan demikian menjadi jelas bahwa proses pendidikan dalam keluarga yang sekarang ini terjadi menjadi sarana untuk menguatkan semangat hidup Kristen dalam diri anak-anak. Berbagai upaya untuk mengajak anak berbelarasa menjadi salah satu bentuk mendengarkan kehendak Tuhan.

Penelitian dalam situasi pandemi ini menunjukkan data bahwa Gereja keluarga bukanlah sesuatu yang diandaikan ada. Melimpahnya pelayanan iman yang berpusat $\mathrm{di}$ gereja ternyata bisa melumpuhkan peran keluarga dalam mendampingi iman anakanak mereka. Bahkan kesadaran akan peran

15 Kevin Schemenauer, "The Works of Mercy: Francis and Family," Journal of Moral Theology Vol. 6 (2017): 32-47.

16 Harls Evan Rianto Siahaan, "Hikmat Sebagai Implikasi Pendidikan Kristiani Dalam Keluarga: keluarga sebagai pewarta Injil di tengah masyarakat juga tidak sangat kentara. Hal ini diperparah dengan kenyataan bahwa orangtua tidak menjadikan kegiatan rohani keluarga sebagai prioritas. Penjarakan sosial memberi ruang kepada berkumpulnya keluarga dan menawarkan kembali kesadaran akan Gereja keluarga sebagai basis hidup beriman.

\section{Pemimpin Keluarga sebagai Pemimpin Spiritual}

Dalam sejarahnya, paham Gereja tentang peran orangtua dan arti menjadi orang tua berubah seturut perkembangan budaya terutama berkaitan dengan gender dan seksualitas. Pada ensiklik Gereja, Casti Connubii (CC) memahami peran suami dan istri dalam konteks hirarki gender. ${ }^{17}$ Istri adalah penolong suami yang mengurus rumah dan dapur, sedang suami menyuplai ekonomi keluarga. Suami juga menjadi kepala keluarga sebagaimana Kristus adalah kepala Gereja, dan istrinya harus tunduk pada suami sebagai kepala. Dalam kasus tertentu, istri bisa menjadi kepala keluarga bila suaminya meninggal atau absen (CC 27). Kesehatan keluarga baik jasmani dan rohani banyak tergantung dari keutamaan dan ker-

Refleksi 1 Raja-Raja 3: 1-15," DUNAMIS: Jurnal Teologi Dan Pendidikan Kristiani 1, no. 1 (2016): 15-30.

${ }^{17}$ Pius XI, "Casti Connubii," Acta apostolicae sedis 22 (1930): 539-592. 
ja keras bapak keluarga. Sampai dengan tahun 1950-an Gereja memahami peran orang tua terbatas pada tindakan merawat anak, mendidik dan memperhatikan hidup keluarga. Hidup seksualitas suami-istri diletakkan dalam kontek prokreasi dan pendidikan anak sebagai tujuan utama membangun keluarga Kristiani. ${ }^{18}$

Seturut paham hak-hak perempuan dan kesejajaran laki-laki dan perempuan, Gereja memberi tempat pada peran perempuan dalam dunia meski peran mereka perlu disesuaikan dengan hakekat kewanitaan mereka. Gaudium et Spes (GS 52) menekankan peran bapak dalam pendidikan anak-anak, sedang kehidupan awal anakanak membutuhkan peran ibu di rumah. Peran domestik dari seorang ibu mendapat perhatian khusus, meski perkembangan sosial dan budaya soal perempuan tidak boleh diabaikan juga. Konsili Vatican II memahami keluarga sebagai "sekolah untuk memperdalam kemanusiaan" (GS 52); "ibu dan perawat pertama dalam pendidikan" (GS 62), "sekolah pertama dari keutamaan sosial yang dibutuhkan setiap masyarakat" (GE 2), "dasar dari masyarakat" (GS 52). Anjuran Gereja Apostolicum Actuositatem (AA) menyatakan orang tua sebagai pewarta utama dan pemberi teladan hidup bagi

18 Jacob Kohlhaas, "Constructing Parenthood: Catholic Teaching 1880 to the Present," Theological Studies 79, no. 3 (2018): 610-33. anak-anak agar mereka bisa memilih jalan hidup (AA 11). Dengan begitu, keluarga memenuhi tugas utama mereka sebagaimana dimaksudkan oleh Allah bahwa lewat doa dan kasih, keluarga menjadi Gereja keluarga yang berpartisipasi dalam ibadah, memperjuangkan keadilan dan meneruskan pelayanan.

Dalam Familiaris Consortio (FC) Yohanes Paulus II memperluas tugas perempuan dalam soal ekonomi dan sosial. Perempuan bisa turut dalam pekerjaan umum untuk mencari uang. Pekerjaan di luar rumah harus ditempatkan dalam konteks peran perempuan sebagai istri dan ibu bagi anak-anaknya (FC 23). Paus tetap menekankan peran perempuan dalam keibuannya. Panggilan keibuan tidak tergantikan dan menjadi hal utama bagi perempuan yang menjadi hakekat seorang perempuan dalam keluarga. Sedangkan tugas bapak menyangkut penyedia ekonomi keluarga, mengasihi anak dan istri, mendidik anak dalam pendidikan.

Ciri khas peranan orangtua selaku pendidik -ialah cinta kasih mereka sebagai orangtua, yang terwujudkan sepenuhnya dalam tugas mendidik, karena tugas itulah yang melengkapi dan menyempurnakan pengabdian kepada kehidupan. Selain menjadi sumber, cinta kasih orangtua me- 
rupakan prinsip yang menjiwai, dan karena itu norma yang mengilhami serta mengarahkan segala kegiatan konkret mendidik, memperkayanya dengan nilai-nilai keramahan, ketabahan, kebaikan hati, pengabdian, sikap tanpa pamrih, dan pengorbanan diri, yang merupakan buah hasil cinta kasih yang paling berharga (FC 36).

Peran kedua orang tua dalam mendidik iman anak sangat sentral. Iman sendiri bisa dipahami sebagai motor pengerak yang dimiliki setiap orang yang memampukan manusia untuk mencapai tujuan akhir hidupnya. ${ }^{19}$ Tentu saja saat anak-anak, mereka belum mengerti seperti apa wujud dari tujuan hidup. Orang tua akan membantu anak-anak sedikit-demi sedikit untuk mengerti ke mana hidup harus melangkah. Dalam kehidupan, iman berperan memberi perspektif manusia dalam melihat realita. Perspektif tersebut di dalamnya memuat inisiatif seseorang untuk mencari sekaligus respon terhadap realitas. Misalnya saja, menghadapi realitas pandemic covid-19, anak-anak akan bertanya, "Mengapa kita harus memakai masker? Mengapa bencana ini terjadi?" Pertanyaan-pertanyaan mereka mengarah pada bagaimana cara pandang orang tua melihat realita dunia ini dalam te-

19 James Fowler menguraikan ada 6 tahap dalam perkembangan iman. Tahap ini disesuaikan dengan perkembangan psikologi dan perkembangan hidup seseorang. James W Fowler and Robin W Levin, rang iman. Hal itulah yang diajarkan pada anak-anak mereka.

Setidaknya orang tua mendampingi iman anak dalam tiga tahap perkembangan. Tahap pertama adalah proyektif - intuitif. ${ }^{20}$ Pada saat anak berusia antara 2-6 tahun, mereka memiliki kemampuan berpikir yang minimalis, tapi sudah memiliki imajinasi untuk memaknai pengalaman. Seorang anak mencoba untuk mengindentifikasi berbagai hal dengan bertanya: "apa itu?" dan “mengapa." Hal tersebut ditujukan untuk mengenali sekaligus mengkonfirmasi pengalaman. Dari konfirmasi tersebut disusun dalam memori imajinasi sekaligus diklasifikasikan. Oleh karena itu, pada tahap ini anak-anak akan melihat realitas dengan fantasi menjadi hal yang tumpang tindih. Implikasinya adalah nilai-nilai keutamaan seperti keberanian, kejujuran, gotong royong lebih mudah untuk ditanamkan lewat cerita, dongeng, atau imajinasi-fantasi. Orang tua bisa mengajari anak-anak dengan mendongeng, menceritakan kisah santo-santa, mengenalkan mukjizat Yesus dalam Kitab Suci, dan lainnya.

Tahap kedua adalah mistis - harafiah. Anak-anak pada usia 7- 12 tahun ada dalam tahap ini. Mereka memiliki sistem pemikiran yang lebih runtut dan konstruktif.

\footnotetext{
"Stages of Faith: The Psychology of Human Development and the Quest for Meaning" (New York: Harper and Row, 1984): 18.

${ }^{20}$ Fowler and Levin, 124.
} 
Berbeda dari tahap sebelumnya, pada tahap ini, kerangka pemahaman serta perspektif lebih logis, afektif, serta berjalan dua arah. Saat mereka bertanya memakai daya imajinasi, dalam diri mereka ada juga usaha untuk mencari pembuktiannya. Dalam perkembangan iman, tahapan ini memiliki proses analogis-kreatif dimana Allah digambarkan memiliki kekuatan magis dan luar biasa. Anak usia ini juga bisa memahami adanya hukuman dan ganjaran dari Allah. Contohnya, apabila seorang anak melakukan hal baik akan mendapatkan berkat dari Allah, sebaliknya kalau berbuat nakal Allah akan menghukumnya. Pada taraf ini, orang tua bisa mendidik anak untuk mengetahui aturan-aturan hidup beriman yang sederhana. Anak-anak perlu belajar apa kewajiban dan hak dari seorang Katolik. Tentu saja semua itu diajarkan dengan bahasa yang sederhana sesuai cara berfikir mereka.

Tahap ketiga adalah sintetis-konvensional. Anak-anak dalam usia 13-18 tahun ada dalam tahap ini. Pada tahap ini, mereka memasuki masa remaja yang ditandai dengan keinginan untuk memiliki relasi yang intim di luar lingkup keluarga. Seorang remaja bertransisi dari identitas diri yang berpusat dalam keluarga dan masuk dalam lingkungan kelompok seumur. Mereka mempunyai pola berpikir yang lebih kritis dan semakin objektif, artinya mampu merefleksikan proses cara berpikirnya sen- diri dan mampu menemukan pelbagai solusi tersendiri yang khas remaja. Sebagian besar remaja mengidentifikasikan iman mereka sama dengan iman kelompok. Orang tua perlu memberi tempat luas bagi anak-anak remaja untuk masuk dalam komunitas seumur misalnya: misdinar, OMK (orang muda Katolik) atau kelompok minat lainnya.

Dalam masa remaja ini, anak remaja berusaha memahami Allah yang transenden: bagaimana memahami Ekaristi? Bagaimana memaknai sakramen tobat? Mereka berusaha melakukan pencarian jadi diri termasuk pencarian identitas iman yang menyapa secara personal. Kadang ada kegagalan dalam memahami Allah dan simbol spiritual dalam agama. Akibat terburuknya anak akan tidak menghargai simbol agama, atau menganggap Tuhan tidak begitu berarti dalam hidupnya. Orang tua perlu memahami sungguh apa yang terjadi pada anak remaja dalam soal krisis iman. Mereka perlu menjaga anak-anak agar tidak jatuh dan meninggalkan agamanya. Menemani anak remaja dalam proses beriman akan memperluas pengalaman hidup orangtua. Pengalaman iman orang tuanya berperan memberikan landasan dan pandangan agar anakanak mereka mampu menjelajahi berbagai pengalaman baru dalam hidup yang lebih luas dan mendalam. 


\section{KESIMPULAN}

Pandemi covid-19 mengurangi relasi antar pribadi dalam diri anak-anak karena adanya pembatasan sosial dan penjarakan fisik (social and physical distancing). Dalam banyak hal relasi sosial ini hanya terbatas di antara anggota keluarga. Orang tua menjadi figur utama karena mereka tidak punya figur lain seperti halnya guru di sekolah, pastor, guru sekolah minggu, dan yang lain yang biasa ditemui sebelum pandemi. Oleh karenanya dialektika proses internalisasi iman sangat tergantung pada cara orang tua mendukung anak dengan berbagai kegiatan yang mengembangkan nilai-nilai iman dalam diri anak-anak. Pandemi ini menjadi tantangan sekaligus peluang bagi umat Katolik untuk kembali menyadari perannya menjadikan keluarga sebagai pusat hidup rohani. Bagi keluarga, mereka ditantang untuk terus mengembangkan peran orang tua dan Gereja keluarga sebagai pusat hidup rohani. Sementara bagi institusi Gereja, para pemimpin harus mencari cara-cara baru bagaimana bisa mendukung keluarga Kristiani untuk mengembangkan peran mereka sebagai pusat hidup rohani sehingga iman anggota keluarga tetap terjaga dan mampu bertahan dalam masa-masa sulit sekalipun.

\section{DAFTAR PUSTAKA}

"Antisipasi Corona, Sejumlah Gereja Katolik Di Keuskupan Jakarta Dan Semarang Gelar Ibadah Online -
Minews ID." Accessed April 28, 2020. https://www.minews.id/news/ antisipasi-corona-sejumlah-gerejakatolik-di-keuskupan-jakarta-dansemarang-gelar-ibadah-online.

Atkinson, Joseph C. "Family as Domestic Church: Developmental Trajectory, Legitimacy, and Problems of Appropriation." Theological Studies 66, no. 3 (2005): 592-604.

Bourg, Florence Caffrey. "Domestic Church: A New Frontier in Ecclesiology." Horizons 29, no. 1 (2002): 42-63.

Fowler, James W, and Robin W Levin. "Stages of Faith: The Psychology of Human Development and the Quest for Meaning." New York: HarperCollins, 1984.

Homili Bapa Uskup Agung Mgr. Robertus Rubiyatmoko: "Sukacita Dalam Kerinduan Akan Allah." Accessed April 28, 2020. https://www. youtube.com/watch? $\mathrm{v}=\mathrm{UCMcREU}$ EfRg\& $\mathrm{t}=3 \mathrm{~s}$.

Inspirasi Hidup\#4: Ini Dia, Harta Yang Melebihi Emas Permata. Accessed April 28, 2020. https://www. youtube.com/watch?v=iulZwzDZ3 bo\&t $=7 \mathrm{~s}$.

Kohlhaas, Jacob. "Constructing Parenthood: Catholic Teaching 1880 to the Present." Theological Studies 79, no. 3 (2018): 610-33.

Last, Richard. "The Neighborhood (Vicus) of the Corinthian Ekklēsia: Beyond Family-Based Descriptions of the First Urban Christ-Believers." Journal for the Study of the New Testament 38, no. 4 (2016): 399425.

Paul, VI. "Gravissimum Educationis." Retrieved May 19 (1965): 2018.

Paul, VI "Lumen Gentium." Encyclical Http://Www.Vatican.va/Archive/Hi 
st_councils/Ii_vatican_council/Doc uments/Vatii_const_19641121_lum en-Gentium_en.Html, 1964.

Pius, XI. "Casti Connubii." Acta Apostolicae Sedis 22 (1930): 53992.

Schemenauer, Kevin. "The Works of Mercy: Francis and Family," Journal of Moral Theology Vol. 6 (2017): 32-47.

Siahaan, Harls Evan Rianto. "Hikmat Sebagai Implikasi Pendidikan Kristiani Dalam Keluarga: Refleksi
1 Raja-Raja 3: 1-15." DUNAMIS: Jurnal Teologi Dan Pendidikan Kristiani 1, no. 1 (2016): 15-30.

Skelley, Michael. The Liturgy of the World: Karl Rahner's Theology of Worship. Collegeville: MN: Liturgical Press, 1991.

Thomas R Blanton, and Raymond Pickett. Paul and Economics. A Handbook. Minneapolis: Fortress Press, 2017.

Wojtyla, Karol. Love and Responsibility. New York: Farrar, Straus, Giroux, 1981. 